\title{
Interactive comment on "Land Subsidence due to groundwater pumping: Hazard Probability Assessment through the Combination of Bayesian Model and Fuzzy Set Theory" by Huijun Li et al.
}

Huijun Li et al.

Ihjun811@163.com

Received and published: 4 January 2021

The comment was uploaded in the form of a supplement:

https://nhess.copernicus.org/preprints/nhess-2020-309/nhess-2020-309-AC1-

supplement.pdf

Interactive comment on Nat. Hazards Earth Syst. Sci. Discuss., https://doi.org/10.5194/nhess- 